\title{
Comparison of Plasma Levels of Mature Adrenomedullin and Natriuretic Peptide as Markers of Cardiac Function in Hemodialysis Patients with Coronary Artery Disease
}

\author{
Akihiko Osajima Masahiro Okazaki Masahito Tamura Hirofumi Anai \\ Narutoshi Kabashima Takeshi Suda Masako Iwamoto Takayuki Ota \\ Yuujiro Watanabe Kaori Kanegae Yasuhide Nakashima
}

Second Department of Internal Medicine, University of Occupational and Environmental Health, School of Medicine, Yahatanishi-ku, Kitakyushu, J apan

\section{Key Words}

Atrial natriuretic peptide - Brain natriuretic peptide .

Cardiac function - Coronary artery disease .

Hemodynamics · Mature adrenomedullin

\begin{abstract}
Background: It has been suggested that, like ANP and BNP, high plasma levels of mature adrenomedullin (mAM) indirectly reflect the severity of heart failure or renal failure. However, the relationship between mAM levels and hemodynamics and cardiac function has not been examined in hemodialysis (HD) patients with coronary artery disease (CAD). The best marker, among mAM, ANP and BNP, for left-ventricular function in those patients is also unclear. Patients and Methods: Plasma levels of mAM, total AM (tAM), ANP and BNP were determined before HD in chronic HD patients with CAD (group $1 ; n=17)$ and were compared with those of HD patients without cardiac disease (group 2; $n=22$ ). We examined their relationship to hemodynamics and cardiac function in group 1 using data obtained by cardiac catheterization. Results: Plasma levels of ANP and BNP were significantly higher in group 1 than in group 2 , but there was no
\end{abstract}

significant difference in plasma levels of mAM and tAM between the two patient groups. Plasma levels of both $\mathrm{mAM}$ and $\mathrm{TAM}$ significantly correlated with right atrial pressure (RAP), and only plasma tAM levels correlated with pulmonary artery pressure (PAP) and pulmonary artery wedge pressure (PAWP). However, no correlations were found between levels of the two forms of AM and ejection fraction (EF). In contrast, plasma ANP and BNP levels significantly correlated with both PAP and PAWP, and also with EF, although they did not correlate with RAP. The correlation of PAP and PAWP with ANP and BNP levels was closer than that with tAM levels. The most significant correlation was between BNP levels and EF ( $r=-0.756, p<0.0001)$. Conclusions: Our results suggest that the mAM level may be less useful than natriuretic peptide levels as a marker of cardiac function in HD patients with CAD, and that the BNP level might be the best indicator of left-ventricular function. In addition, cardiac disease such as CAD may have a minor impact on mAM levels compared to renal failure.

Copyright $\odot 2002$ S. Karger AG, Basel

\begin{tabular}{ll}
\hline KARGER & ( ) 2002 S. Karger AG, Basel \\
Fax +41 61306 1234 $34-2766 / 02 / 0924-0832 \$ 18.50 / 0$ \\
$\begin{array}{l}\text { E-Mail karger@karger.ch } \\
\text { www.karger.com }\end{array}$ & $\begin{array}{l}\text { Accessible online at: } \\
\text { www.karger.com/journals/nef }\end{array}$
\end{tabular}

Akihiko Osajima, MD

Second Department of Internal Medicine

University of Occupational and Environmental Health, School of Medicine

1-1 Iseigaoka, Yahatanishi-ku, Kitakyushu 807-8555 (Japan)

Tel. +8193603 1611, Fax +81936916913, E-Mail mdosa@clnc.uoeh-u.ac.jp 


\section{Introduction}

Cardiac diseases such as coronary artery disease (CAD) and valvular heart disease are frequently present in patients undergoing hemodialysis (HD) therapy, and the prognosis in such patients is worse than in those without cardiac disease [1]. In the majority of such cases, CAD, including myocardial infarction and angina pectoris, has been reported to be the most important determinant of survival [1]. Previous studies reported that plasma levels of atrial natriuretic peptide (ANP) and brain natriuretic peptide (BNP) were significantly elevated in proportion with the severity of heart failure in patients with cardiac disease, suggesting that the natriuretic peptides may be good markers for cardiac function [2, 3]. Significantly high levels of these peptides were also demonstrated in patients with chronic renal failure, especially in those on HD [4-7], which may be explained by both the decreased clearance of these peptides and by increased body fluid volume [4-7]. Recently, we have reported that plasma ANP and BNP levels were further increased in HD patients with CAD compared to those without cardiac disease [8]. Our study using cardiac catheterization also showed that plasma ANP and BNP levels correlated well with pulmonary artery pressure (PAP), pulmonary artery wedge pressure (PAWP), left-ventricular end-diastolic pressure (LVEDP) and left-ventricular ejection fraction (LVEF), and that the most significant correlation was between BNP levels and LVEF [8]. These results suggest that cardiac disease such as CAD, as well as renal failure, may have a major impact on plasma ANP and BNP levels and that levels of the two natriuretic peptides could be useful markers for left ventricular function.

Adrenomedullin (AM), a hypotensive and natriuretic peptide [9], consists of an amidated mature form (mAM) and an intermediate form in human plasma, of which only mAM exerts biological activity [10]. AM functions as a paracrine and/or autocrine factor in the regulation of cardiovascular homeostasis [11], although the clinical significance of $\mathrm{mAM}$ is not fully understood. Our recent study showed that, like ANP and BNP, plasma levels of $\mathrm{mAM}$ are significantly elevated in patients with chronic renal failure on HD [12] as well as in those with heart failure [13]. These results suggest that mAM may be stimulated by the retention of body fluid in a manner similar to the two natriuretic peptides $[2,4,6]$, probably acting as a defensive mechanism in certain pathological conditions, such as heart failure and renal failure, through its vasodilator and natriuretic effects [14]. Previous studies have demonstrated that plasma levels of mAM significantly correlated with both ANP and BNP, and also with several cardiac parameters such as RAP, PAP and PAWP in patients with heart failure $[13,15]$. These results suggest that plasma levels of mAM may indirectly reflect hemodynamics and cardiac function, although whether significant correlations exist between mAM levels and LVEF remains controversial $[13,16]$. Thus, determination of plasma mAM levels as well as plasma ANP and BNP levels is considered as a useful non-invasive tool for evaluation of hemodynamics and cardiac function. However, the relationship between mAM levels and hemodynamics and cardiac function has not been examined in HD patients with CAD. Whether mAM levels are superior to ANP and BNP levels as markers of left-ventricular function in those patients is also unclear.

In the present study, we compared plasma levels of mAM in HD patients with CAD to those in HD patients without cardiac disease, and examined the relationship between mAM levels and hemodynamics and left-ventricular function, using data obtained by cardiac catheterization. Furthermore, we compared the usefulness of mAM levels with that of ANP and BNP levels, as a marker of cardiac function.

\section{Patients and Methods}

\section{Patients}

The study patients comprised two groups: chronic HD patients with CAD (group 1, $\mathrm{n}=17 ; 12$ men and 5 women) and those without obvious cardiac disease (group 2, $\mathrm{n}=22 ; 14$ men and 8 women), who had not participated in our previous study [8] (table 1). The underlying renal diseases in the study population included chronic glomerulonephritis (9 in group 1 and 19 in group 2), benign nephrosclerosis (5 and 2, respectively) and idiopathic ( 3 and 1 , respectively). There was no significant difference between patients in the two groups with respect to age, duration of HD, systolic or diastolic blood pressure, cardiothoracic ratio (CTR), blood urea nitrogen, creatinine, albumin or hematocrit. The diagnosis of CAD was made on the basis of clinical histories, physical examinations, chest X-rays, electrocardiograms, and echocardiograms, in addition to the cardiac catheterization data. CAD was defined on cardiac catheterization as more than $75 \%$ reduction of luminal diameter of one or more coronary arteries. Among the patients, 9 had effort angina and 8 had an old myocardial infarction. Since the levels of mAM, total AM (tAM), ANP and BNP are usually markedly increased in patients with congestive heart failure $[13,16,17]$, acute myocardial infarction $[3,15,18]$, cardiac valvular disease $[17,19]$ and cardiomyopathy [20], patients with these abnormalities were excluded from the study. In group 2, cardiac disease was ruled out based on clinical history, physical examination, and the results of ECG, chest X-ray and echocardiography. In both groups, patients were excluded if they had cardiac arrhythmias, uncontrolled hypertension, diabetes mellitus, chronic pulmonary disease or advanced liver disease. Medications such as antihypertensive agents, platelet aggregation inhibitors, and vasodilators were 
Table 1. Characteristics of hemodialysis patients with coronary artery disease (group 1) or without cardiac disease (group 2)

\begin{tabular}{lccc}
\hline & $\begin{array}{c}\text { Group 1 } \\
(\mathrm{n}=17)\end{array}$ & $\begin{array}{c}\text { Group 2 } \\
(\mathrm{n}=22)\end{array}$ & Significance \\
\hline Age, years & $63 \pm 12$ & $56 \pm 3$ & $\mathrm{NS}$ \\
Sex (M/F) & $14 / 3$ & $14 / 3$ & $\mathrm{NS}$ \\
HD duration, years & $12 \pm 9$ & $10 \pm 6$ & $\mathrm{NS}$ \\
Systolic BP, mm Hg & $161 \pm 22$ & $149 \pm 4$ & $\mathrm{NS}$ \\
Diastolic BP, mm Hg & $67 \pm 15$ & $79 \pm 2$ & $\mathrm{NS}$ \\
CTR, \% & $52.6 \pm 6.0$ & $49.5 \pm 1.0$ & $\mathrm{NS}$ \\
BUN, mg/dl & $54 \pm 18$ & $57 \pm 12$ & $\mathrm{NS}$ \\
Creatinine, mg/dl & $9.1 \pm 2.6$ & $10.7 \pm 0.4$ & $\mathrm{NS}$ \\
Albumin, g/dl & $3.9 \pm 0.3$ & $3.9 \pm 0.1$ & $\mathrm{NS}$ \\
Hct, \% & $32.0 \pm 7.0$ & $30.2 \pm 5.7$ & $\mathrm{NS}$ \\
Interdialysis weight gain, g & $2,762 \pm 231$ & $2,633 \pm 346$ & $\mathrm{NS}$ \\
\hline
\end{tabular}

$\mathrm{HD}=$ Hemodialysis; $\mathrm{BP}=$ blood pressure $; \mathrm{CTR}=$ cardiothoracic ratio; $\mathrm{BUN}=$ blood urea nitrogen. NS = Not significant. commonly used as needed. All patients had no residual renal function, and no difference in interdialysis weight gain was observed between the two groups at the start of the HD treatment (table 1). Ultrafiltration was volumetrically controlled in all patients and the rate of fluid removal was recorded hourly during HD. All patients underwent regular sessions of HD for $4 \mathrm{~h}$ three times weekly. In all patients, commercial high flux dialyzers with polysulfone or polyester-polymer alloy membranes were used. Heparin was used as an anticoagulant in all patients with an initial loading dose of 1,000 IU followed by continuous infusion of $500 \mathrm{IU} / \mathrm{h}$. The blood flow was usually $150 \mathrm{ml} / \mathrm{min}$, and the dialyzate was bicarbonate-buffered and contained $141 \mathrm{~m} M$ sodium. Body fluid was withdrawn and the ultimate goal was to reach a clinically determined dry weight (DW) after dialysis, that is, a condition in which no clinical signs of hypervolemia such as edema, dyspnea, or excessive increase in arterial blood pressure, were evident. This was established under the supervision of an experienced nephrologist. We also studied 11 healthy control subjects ( 9 men and 2 women; age $29 \pm 3$ years), who were not on any medication. Informed consent was obtained from each participant prior to initiation of the study.

\section{Study Protocol}

Prior to the commencement of dialysis, patients were kept in the supine position in the dialysis room for at least $30 \mathrm{~min}$ to stabilize their physical condition. Blood pressure and heart rate were recorded hourly in this position, and body weight was recorded before and after HD. The CTR was determined by one examiner using the chest X-ray film obtained before HD. Plasma mAM, tAM, ANP and BNP levels were determined in blood samples withdrawn from the arteriovenous fistula immediately before the HD session. Before a regularly scheduled HD, all patients of group 1 underwent cardiac catheterization, including left ventriculography and coronary arteriography. LVEDP and LVEF were calculated by the area-length method. At the same time, a Swan-Ganz catheter was inserted into the femoral vein to measure RAP, PAP and PAWP. Cardiac output was calculated by the thermodilution method. Prior to the procedure, blood samples for mAM, tAM, ANP and BNP were also withdrawn from the femo- ral vein during bed rest. In the control group, blood was drawn from the antecubital vein after a 15 -minute rest in the supine position. Blood samples were collected in chilled tubes containing EDTA-2Na and aprotinin, and immediately transported on ice to the laboratory. Plasma was separated by centrifugation and stored at $-70^{\circ} \mathrm{C}$ until analysis. ANP and BNP were determined by commercially available radioimmunoassay kits, namely, Siono-RIA ANP and BNP (Shionogi Co., Osaka, Japan) $[8,12]$. Plasma mAM and tAM were measured with radioimmunoassays specific for $\alpha$-human $\mathrm{mAM}$ and tAM, respectively (Shino RIA mature AM kit, RIA AM kit, Shionogi Co.) [12]. The intra-assay coefficients of variation for ANP, BNP, mAM and tAM were 5.6, 5.8, 6.2 and 5.8\%, respectively, and their interassay coefficients of variation were 5.6, 6.2, 5.0 and 5.6\%, respectively.

\section{Statistical Analysis}

All values are presented as mean \pm SD. The unpaired or paired Student's $t$ test was performed to determine the presence of significant differences between the two groups, if appropriate. A value of $\mathrm{p}<0.05$ was considered significant. Correlation coefficients were calculated using linear regression analysis.

\section{Results}

Effects of CAD on Plasma Levels of mAM, tAM, ANP and BNP before the HD Session in Groups 1 and 2

Plasma levels of mAM, tAM, ANP and BNP before $\mathrm{HD}$ are shown in figure 1. In both groups 1 and $2, \mathrm{mAM}$ levels before HD (group 1: $2.2 \pm 0.8 \mathrm{fmol} / \mathrm{ml}$, group 2: 2.4 $\pm 0.6 \mathrm{fmol} / \mathrm{ml}$ ) were significantly higher than in control subjects $(1.1 \pm 0.2 \mathrm{fmol} / \mathrm{ml})$, but no statistical difference was observed between mAM levels of the two patient groups. Similar results were obtained for plasma levels of tAM (group 1: $27.0 \pm 12.1 \mathrm{fmol} / \mathrm{ml}$, group 2: $23.6 \pm$ 


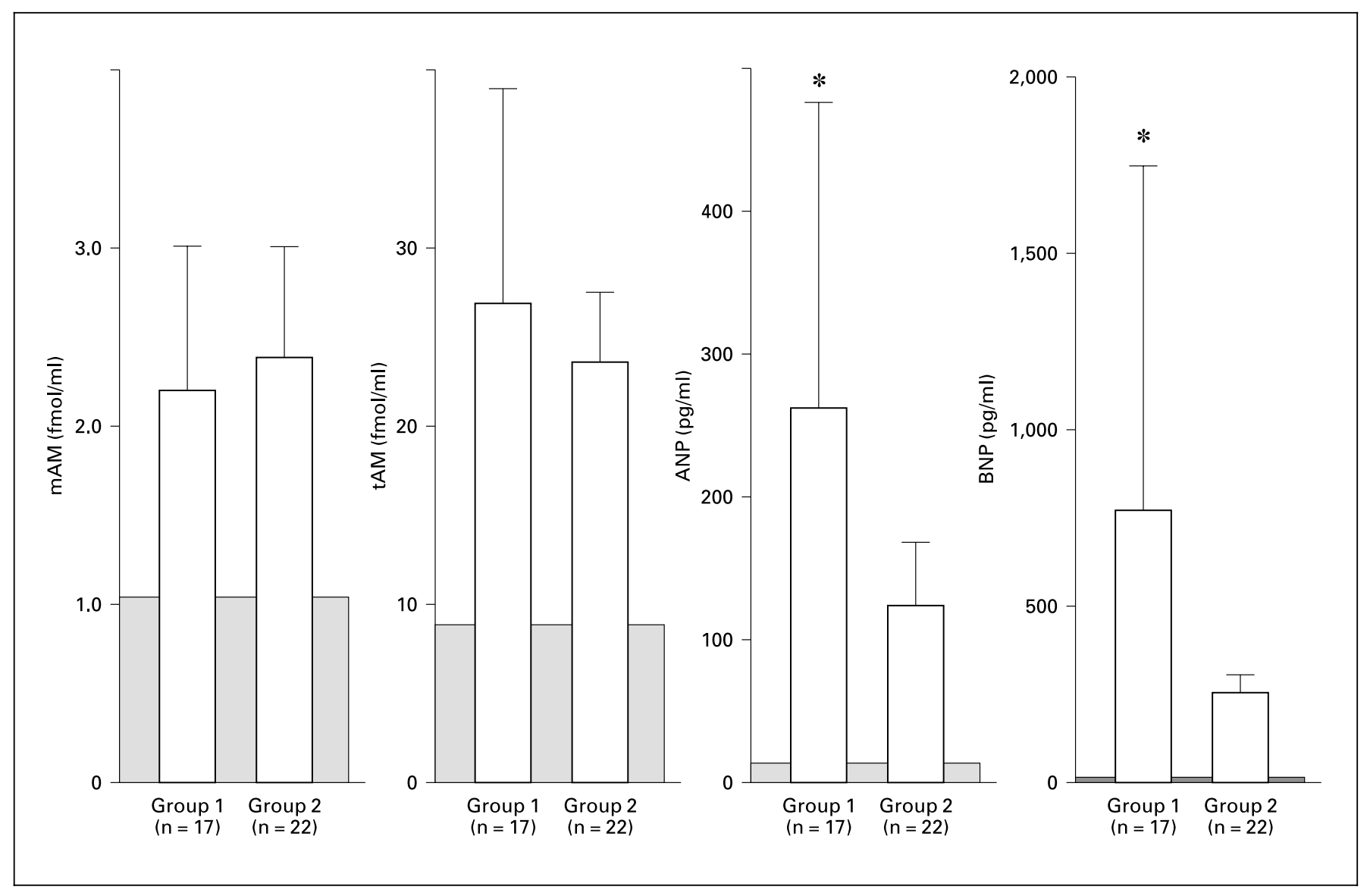

Fig. 1. Plasma concentrations of mature adrenomedullin (mAM), total adrenomedullin (tAM), atrial natriuretic peptide (ANP) and brain natriuretic peptide (BNP) before hemodialysis (HD), in HD patients with coronary artery disease (group 1) or without cardiac disease (group 2). Dotted bars represent data of normal subjects. Values are expressed as mean $\pm \mathrm{SD} .{ }^{*} \mathrm{p}<0.01$, compared with group 2 .

$4.0 \mathrm{fmol} / \mathrm{ml}$, control subjects: $9.1 \pm 2.1 \mathrm{fmol} / \mathrm{ml})$. As described previously [8], ANP and BNP levels were significantly higher in both groups (group 1:261 $\pm 210 \mathrm{pg} /$ $\mathrm{ml}$ and $772 \pm 966 \mathrm{pg} / \mathrm{ml}$, group 2: $123 \pm 44 \mathrm{pg} / \mathrm{ml}$ and $261 \pm 44 \mathrm{pg} / \mathrm{ml}$, respectively) compared to the control values (ANP: $18.6 \pm 9.9 \mathrm{pg} / \mathrm{ml}$, BNP: $7.7 \pm 7.6 \mathrm{pg} / \mathrm{ml}$ ). ANP and BNP levels in group 1 were significantly higher than in group $2(\mathrm{p}<0.05)$, and BNP levels were markedly higher than those of ANP, especially in group 1.

\section{Correlations among $M A M, t A M, A N P$ and $B N P$ before $H D$ in Groups 1 and 2}

The results of correlation analyses among $\mathrm{mAM}$, tAM, ANP and BNP before the HD session are shown in table 2. Significant correlations existed between the two forms of AM as well as between the two natriuretic peptides in both groups. In group 1, tAM levels correlated significantly with ANP and BNP levels $(\mathrm{p}<0.05)$, but no correlations were observed between mAM levels and levels of the two natriuretic peptides. As shown in our recent report [12], levels of both $\mathrm{MAM}$ and tAM correlated significantly with BNP levels in group 2, whereas they did not correlate with ANP levels. The correlation of BNP with $\mathrm{mAM}$ was closer than that with tAM ( $p<0.005$ vs. $\mathrm{p}<0.05)$.

Correlation between $m A M$, tAM, ANP and BNP before $H D$ and Various Cardiac Parameters Measured by

Cardiac Catheterization in Group 1

Table 3 shows the correlations between mAM, tAM, and natriuretic peptides and LVEF and hemodynamic parameters. Plasma levels of mAM and tAM weakly but significantly correlated with RAP, but only tAM levels correlated with PAP and PAWP. Plasma levels of both 
Table 2. Correlations among mAM, tAM, ANP and BNP in hemodialysis patients with coronary artery disease (group 1) or without cardiac disease (group 2)

\begin{tabular}{llc}
\hline & $\begin{array}{l}\text { Regression } \\
\text { coefficient }\end{array}$ & p value \\
\hline Group 1 & & \\
mAM vs. tAM & 0.715 & 0.0013 \\
mAM vs. ANP & 0.104 & 0.6918 \\
mAM vs. BNP & 0.114 & 0.6629 \\
tAM vs. ANP & 0.512 & 0.0355 \\
tAM vs. BNP & 0.592 & 0.0124 \\
ANP vs. BNP & 0.882 & $<0.0001$ \\
\hline Group 2 & & \\
mAM vs. tAM & 0.790 & $<0.0001$ \\
mAM vs. ANP & 0.340 & 0.3001 \\
mAM vs. BNP & 0.602 & $<0.005$ \\
tAM vs. ANP & 0.201 & 0.5079 \\
tAM vs. BNP & 0.418 & $<0.05$ \\
ANP vs. BNP & 0.820 & $<0.0001$ \\
\hline
\end{tabular}

$\mathrm{ANP}=$ Atrial natriuretic peptide; $\mathrm{BNP}=$ brain natriuretic peptide; $\mathrm{mAM}=$ mature adrenomedullin; $\mathrm{tAM}=$ total adrenomedullin .

mAM and tAM did not correlate with LVEDP and LVEF. In contrast, plasma ANP and BNP levels correlated significantly with PAP and PAWP, and also with LVEF, although they did not correlate with RAP [8]. The correlation of PAP and PAWP with ANP and BNP levels was closer than that with tAM levels. The most significant correlation was between BNP levels and LVEF $(r=-0.756$, $\mathrm{p}<0.0001)$.

Correlation between $M A M, t A M, A N P$ and $B N P$ and the Severity of CAD Evaluated by Cardiac

\section{Catheterization}

Table 4 shows the plasma levels of those peptides and the hemodynamics data including LVEF levels measured by echocardiography, according to the severity of CAD evaluated by cardiac catheterization. Seven patients had single-vessel and 10 had multivessel CAD. We found that LVEF measurements obtained by echocardiography were consistent with those obtained by cardiac catheterization. The LVEF levels in HD patients with severe CAD were significantly lower than in those with mild CAD, although there was no difference in the hemodynamics data other than LVEF between the two patient groups. We noted no correlations between the levels of both mAM and tAM and the severity of CAD. ANP levels tended to correlate with the severity of CAD, but it was not statistically sig-
Table 3. Correlations between natriuretic peptides and left-ventricular function or hemodynamics measured by cardiac catheterization in hemodialysis patients with coronary artery disease

\begin{tabular}{llll}
\hline & & $\begin{array}{c}\text { Regression } \\
\text { coefficient }\end{array}$ & p value \\
\hline RAP & vs. mAM & 0.515 & 0.0414 \\
& vs. tAM & 0.547 & 0.0283 \\
& vs. ANP & 0.360 & 0.1714 \\
& vs. BNP & 0.328 & 0.2155 \\
\hline PAP & vs. mAM & 0.378 & 0.1484 \\
& vs. tAM & 0.648 & 0.0066 \\
& vs. ANP & 0.744 & 0.0009 \\
& vs. BNP & 0.759 & 0.0006 \\
\hline PAWP & vs. mAM & 0.309 & 0.2450 \\
& vs. tAM & 0.491 & 0.0500 \\
& vs. ANP & 0.541 & 0.0306 \\
& vs. BNP & 0.565 & 0.0227 \\
\hline LVEDP & vs. mAM & -0.017 & 0.9495 \\
& vs. tAM & 0.435 & 0.0925 \\
& vs. ANP & 0.622 & 0.0076 \\
& vs. BNP & 0.631 & 0.0067 \\
\hline LVEF & vs. mAM & 0.087 & 0.7499 \\
& vs. tAM & -0.386 & 0.1392 \\
& vs. ANP & -0.598 & 0.0112 \\
& vs. BNP & -0.756 & 0.0004 \\
\hline
\end{tabular}

For abbreviations, see table 2. RAP $=$ Right atrial pressure; $\mathrm{PAP}=$ pulmonary artery pressure; $\mathrm{PAWP}=$ pulmonary artery wedge pressure; LVEDP = left-ventricular end-diastolic pressure; $\mathrm{LVEF}=$ left-ventricular ejection fraction.

nificant, as shown in our previous report [8]. In contrast, BNP levels in patients with severe CAD were significantly higher than in patients with mild CAD.

\section{Discussion}

This study is the first to demonstrate the lack of significant difference in plasma levels of $\mathrm{mAM}$ before a HD session between HD patients with CAD and those without cardiac disease, suggesting that cardiac disease such as CAD had a minor impact on mAM levels compared to the impact of renal failure. From the data obtained by cardiac catheterization, our results also indicate that the mAM level may be less useful than ANP and BNP levels as a marker for cardiac function in HD patients with CAD, and that the BNP level might be the optimal indicator for left ventricular function. 
Table 4. Plasma levels of mAM, tAM, ANP and BNP and the hemodynamics data according to the severity of coronary artery disease evaluated by cardiac catheterization in hemodialysis patients with coronary artery disease

\begin{tabular}{|c|c|c|c|c|c|c|c|c|c|c|}
\hline & $\begin{array}{l}\mathrm{mAM} \\
\mathrm{fmol} / \mathrm{ml}\end{array}$ & $\begin{array}{l}\mathrm{tAM} \\
\mathrm{fmol} / \mathrm{ml}\end{array}$ & $\begin{array}{l}\text { ANP } \\
\mathrm{pg} / \mathrm{ml}\end{array}$ & $\begin{array}{l}\mathrm{BNP} \\
\mathrm{pg} / \mathrm{ml}\end{array}$ & $\begin{array}{l}\text { RAP } \\
(1 \sim 10) \\
\mathrm{mg} \mathrm{Hg}\end{array}$ & $\begin{array}{l}\text { PAP } \\
(9 \sim 16) \\
\mathrm{mm} \mathrm{Hg}\end{array}$ & $\begin{array}{l}\text { PAWP } \\
(1 \sim 10) \\
\mathrm{mm} \mathrm{Hg}\end{array}$ & $\begin{array}{l}\text { LVEDP } \\
(3 \sim 12) \\
\mathrm{mm} \mathrm{Hg}\end{array}$ & $\begin{array}{l}\text { LVEF } \\
(60 \sim 80) \\
\%\end{array}$ & $\begin{array}{l}\text { LVEF (UCG) } \\
(60 \sim 80) \\
\%\end{array}$ \\
\hline $\begin{array}{l}1 \text { vessel } \\
(\mathrm{n}=7)\end{array}$ & $\begin{array}{r}2.2 \\
\pm 0.9\end{array}$ & $\begin{array}{r}26 \\
\pm 10\end{array}$ & $\begin{array}{r}189 \\
\pm 50\end{array}$ & $\begin{array}{r}430 \\
+267\end{array}$ & $\begin{array}{r}5 \\
\pm 2\end{array}$ & $\begin{array}{r}19 \\
\pm 8\end{array}$ & $\begin{array}{r}13 \\
\pm 7\end{array}$ & $\begin{array}{r}16 \\
\pm 10\end{array}$ & $\begin{array}{r}67 \\
\pm 13\end{array}$ & $\begin{array}{r}63 \\
\pm 18\end{array}$ \\
\hline $\begin{array}{l}2 \text { or } 3 \text { vessels } \\
(n=10)\end{array}$ & $\begin{array}{r}2.1 \\
\pm 0.8\end{array}$ & $\begin{array}{r}28 \\
\pm 14\end{array}$ & $\begin{array}{r}311 \\
\pm 264\end{array}$ & $\begin{array}{r}1,082^{+} \\
\pm 1,108\end{array}$ & $\begin{array}{r}5 \\
\pm 3\end{array}$ & $\begin{array}{r}18 \\
\pm 8\end{array}$ & $\begin{array}{r}10 \\
\pm 4\end{array}$ & $\begin{array}{r}14 \\
\pm 7\end{array}$ & $\begin{array}{r}56^{+} \\
\pm 16\end{array}$ & $\begin{array}{r}52^{+} \\
\pm 14\end{array}$ \\
\hline $\begin{array}{l}\text { Group } 2 \\
(\mathrm{n}=22)\end{array}$ & $\begin{array}{r}2.4 \\
\pm 0.6\end{array}$ & $\begin{array}{r}23 \\
\pm 4\end{array}$ & $\begin{array}{r}123 \\
\pm 44\end{array}$ & $\begin{array}{r}261 \\
\pm 44\end{array}$ & & & & & & \\
\hline
\end{tabular}

For abbreviations, see tables 2 and 3.1 vessel = Hemodialysis patients with involvement of a single coronary artery; 2 or 3 vessels = hemodialysis patients with involvement of two or three coronary arteries; group $2=$ hemodialysis patients without cardiac disease. $\mathrm{UCG}=$ Echocardiography. Values are expressed as mean $\pm \mathrm{SD} .{ }^{+} \mathrm{p}<0.05$, compared with the 1-vessel group.

It has been suggested that, like ANP and BNP, volume overload may be a stimulus for synthesis and secretion of AM by vascular endothelial [21] and smooth muscle cells [22], despite the differences in their intracellular signaling systems [9, 23-26]. In addition, it has been reported that the failing ventricular myocardium itself may be a source of increased AM production [27, 28]. Thus, it is probable that $\mathrm{mAM}$ acts as a defensive mechanism through its vasodilator and natriuretic effects in certain pathological conditions such as heart failure and renal failure [13,29], in a manner similar to the two natriuretic peptides. We have recently demonstrated the presence of significantly high plasma levels of ANP and BNP in HD patients with CAD compared with those without cardiac disease, indicating that $\mathrm{CAD}$ and renal failure have an additive effect on plasma ANP and BNP levels [8]. In the present study, we demonstrated the presence of significantly high plasma levels of $\mathrm{mAM}$ in HD patients compared to those in healthy subjects, consistent with previous findings [12, 29-33]. However, in our present study, we observed no additive effects of CAD and renal failure on plasma mAM levels, suggesting that regulation of AM secretion/metabolism may be distinct from that of the natriuretic peptides. We cannot explain the reason for this; however, it could possibly be due to a smaller amount of AM secreted from the failing heart compared with that of natriuretic peptides [27]. Based on the fact that the majority of our patients had a relatively preserved left-ventricular function, a state of volume overload rather than cardiac dysfunction may have contributed to the elevated plasma mAM levels observed in our study. Our results suggest that cardiac disease such as CAD had a minor impact on mAM levels compared to renal failure and that volume overload may have a major impact on mAM levels.

Previous studies have shown that plasma levels of both mAM and tAM correlated significantly with cardiac parameters such as RAP, PAP and PAWP in patients with heart failure, suggesting that mAM may be a useful marker for hemodynamics and cardiac function $[13,16]$. In the present study in HD patients with CAD, we demonstrated for the first time that the correlation of PAP and PAWP with ANP and BNP levels was closer than that with tAM levels, and that levels of both MAM and tAM failed to correlate with LVEDP and LVEF. Furthermore, there was a significant correlation between levels of the two natriuretic peptides and LVEDP or LVEF, with the most significant correlation noted between BNP levels and $\operatorname{LVEF}(r=-0.756, p<0.0001)$, as described previously [8]. Our results also showed that BNP levels well reflected the severity of CAD, but no correlation was found between the two forms of $\mathrm{AM}$ and the severity of CAD. These results strongly indicate that mAM levels may be less useful than natriuretic peptide levels as markers of cardiac function in HD patients with CAD, and that BNP levels could be the best indicators of left ventricular function. Our finding of a lack of significant correlation between mAM levels and LVEF may be consistent with a previous study in patients with heart failure [13], although this remains controversial [16]. This may be explained by the differences in the primary cause of heart failure or by the severity of left-ventricular dysfunction in the patients studied, in addition to the differences in the 
pathological conditions between the previous studies (patients with heart failure) $[13,16]$ and ours (HD patients with $\mathrm{CAD}$ ). Another implication from our present study is that plasma levels of $\mathrm{mAM}$, but not those of ANP, correlated with RAP, suggesting that plasma levels of mAM may be useful markers of volume status in HD patients with cardiac disease such as CAD. As described in our recent study [8], the absence of a significant correlation between ANP levels and RAP may be explained by the fact that the levels of RAP obtained in our study were almost within the normal range (less than $10 \mathrm{~mm} \mathrm{Hg}$ ), and elevated ANP levels may be reflected by PAWP levels rather than those of RAP.

Our present study revealed significant correlations between the two forms of AM as well as between the two natriuretic peptides in HD patients with $\mathrm{CAD}$, which is consistent with our recent findings in HD patients without cardiac disease [12] and the previous results in patients with heart failure [13, 29]. Previous studies showed that $\mathrm{mAM}$ and $\mathrm{tAM}$ significantly correlated with ANP and BNP in relation to the severity of diseases such as heart failure [13, 16] and hypertension [34]. In the present study, plasma levels of tAM correlated significantly with levels of both ANP and BNP in HD patients with $\mathrm{CAD}$, whereas no correlation was observed between mAM levels and natriuretic peptide levels. These results differed from those for HD patients without cardiac disease (group 2), in whom both mAM and tAM significantly correlated with BNP levels but not with ANP levels [Suda et al., in press]. We cannot explain the reason, but it could reflect differences in the associated pathological conditions. Further studies are required to clarify the clinical significance of $\mathrm{mAM}$ in certain pathological conditions, where cardiac disease and renal failure coexist.

We conclude that the mAM level may be less useful than natriuretic peptide levels as a marker of cardiac function in HD patients with CAD, and that the BNP level could be the best indicator of left-ventricular function. Unlike the two natriuretic peptides, plasma mAM levels may closely reflect volume status rather than cardiac performance status.

\section{Acknowledgments}

The authors are grateful to Akiko Sugimoto for technical assistance. This work was supported by grants from the Ministry of Education, Science and Culture of Japan (A.O., No. 11671065), and the Renal Anemia Foundation, Japan (A.O., M.T.).

\section{References}

1 Parfrey PS, Foley RN, Harnett JD, Kent GM, Murray D, Barre PE: Outcome and risk of ischemic heart disease in chronic uremia. Kidney Int 1996;49:1428-1434.

2 Raine AEG, Erne P, Burgisser E, Muller FB, Bolli P, Burkart F, Buhler FR: Atrial natriuretic peptide and atrial pressure in patients with congestive heart failure. N Engl J Med 1986; 315:533-537.

3 Morita E, Yasue H, Yoshimura M, Ogawa H, Jougasaki M, Matsumura T, Mukoyama M, Nakao K: Increased plasma levels of brain natriuretic peptide in patients with acute myocardial infarction. Circulation 1993;88:82-91.

4 Saxenhofer H, Gnadinger MP, Weidmann P, Shaw S, Schohn D, Hess C, Uehlinger DE, Jahn $\mathrm{H}$ : Plasma levels and dialysance of atrial natriuretic peptide in terminal renal failure. Kidney Int 1987;32:554-561.

5 Kohse KP, Feifel K, Mayer-Wehrstein R: Differential regulation of brain and atrial natriuretic peptides in hemodialysis patients. Clin Nephrol 1993;40:83-90

6 Ishizaka Y, Yamamoto Y, Fukunaga T, Yokota N, Kida O, Kitamura K, Kangawa K, Minamino N, Matsuo H, Eto T: Plasma concentration of human brain natriuretic peptide in patients on hemodialysis. Am J Kidney Dis 1994;24: 461-472.
7 Ishizaka Y, Yamamoto Y, Tanaka M, Kato F, Ishizaka Y, Yokota N, Kato J, Kitamura K, Eto T, Kangawa K, Minamino N, Matsuo H: Molecular forms of human brain natriuretic peptide (BNP) in plasma of patients on hemodialysis (HD). Clin Nephrol 1995;43:237-242.

8 Osajima A, Okazaki M, Kato H, Anai H, Tsuda Y, Segawa K, Tanaka H, Tamura M, Takasugi M, Nakashima Y: Clinical significance of natriuretic peptides and cyclic GMP in hemodialysis patients with coronary artery disease. Am J Nephrol 2001;21:112-119.

9 Kitamura K, Kangawa K, Kawamoto M, Ichiki Y, Nakamura S, Matsuo H, Eto T: Adrenomedullin: A novel hypotensive peptide isolated from pheochromocytoma. Biochem Biophys Res Commun 1993;192:553-560.

10 Kitamura K, Kato J, Kawamoto M, Tanaka M, Chino N, Kangawa K, Eto T: The intermediate form of glycine-extended adrenomedullin is the major circulating molecular form in human plasma. Biochem Biophys Res Commun 1998; 244:551-555.

11 Edwards RM, Trizna W, Aiyar N: Adrenomedullin: A new peptide involved in cardiorenal homeostasis? Exp Nephrol 1997;5:18-22.
12 Suda $\mathrm{T}$, Osajima A, Iwamoto $\mathrm{M}$, Anai $\mathrm{H}$, Tamura M, Kabashima N, Ota T, Watanabe Y, Kanegae K, Okazaki M, Nakashima Y: The mature form of adrenomedullin correlates with brain natriuretic peptide in plasma of chronic hemodialysis patients. Clin Nephrol 2002;57: 444-457.

13 Hirayama N, Kitamura K, Imamura T, Kato J, Koiwaya Y, Tsuji T, Kangawa K, Eto T: Molecular forms of circulating adrenomedullin in patients with congestive heart failure. J Endocrinol 1999;160:297-330.

14 Massart PE, Hodeige D, Donckier J: Adrenomedullin: View on a novel vasodilatory peptide with natriuretic properties. Acta Cardiol 1996; 51:259-269.

15 Asakawa H, Nishikimi T, Suzuki T, Hara S, Tsubokou Y, Yagi H, Yabe A, Tsuchiya N, Horinaka S, Kangawa K, Matsuoka H: Elevation of two molecular forms of adrenomedullin in plasma and urine in patients with acute myocardial infarction treated with early coronary angioplasty. Clin Sci 2001;100:117-126.

16 Nishikimi Saito Y, Kitamura K, Ishimutsu T, Eto T, Kangawa K, Matsuo H, Omae T, Matsuoka $\mathrm{H}$ : Increased plasma levels of adrenomedullin in patients with heart failure. J Am Coll Cardiol 1995;26:1424-1431. 
17 Yoshimura M, Yasue H, Okumura K, Ogawa H, Jougasaki M, Mukoyama M, Nakao K, Imura H: Different secretion patterns of atrial natriuretic peptide and brain natriuretic peptide in patients with congestive heart failure. Circulation 1993;87:464-469.

18 Kobayashi K, Kitamura K, Hirayama N, Date H, Kashiwagi T, Ikushima I, Hanada Y, Nagatomo Y, Takenaga M, Ishikawa T, Imamura T, Koiwaya Y, Eto T: Increased plasma adrenomedullin in acute myocardial infarction. Am Heart J 1996;131:676-680.

19 Nishikimi T, Nagata S, Sasaki T, Tomimoto S Matsuoka H, Takishita S, Kitamura K, Miyata A, Matsuo H, Kangawa K: Plasma concentration of adrenomedullin correlates with the extent of pulmonary hypertension in patients with mitral stenosis. Heart 1997;78:390-395

20 Yasue H, Obata K, Okumura K, Kurose M, Ogawa H, Matsuyama K, Jougasaki M, Saito Y, Nakao K, Imura H: Increased secretion of atrial natriuretic polypeptide from the left ventricle in patients with dilated cardiomyopathy. J Clin Invest 1989;83:46-51.

21 Sugo S, Minamino N, Kangawa K, Miyamoto K, Kitamura K, Sakata J, Eto T, Matsuo H: Endothelial cells actively synthesize and secrete adrenomedullin. Biochem Biophys Res Commun 1994;201:1160-1166.
22 Sugo S, Minamino N, Shoji H, Kangawa K, Kitamura K, Eto T, Matsuo H: Production and secretion of adrenomedullin from vascular smooth muscle cells: Augmented production by tumor necrosis factor- $\alpha$. Biochem Biophys Res Commun 1994;203:719-726.

23 Waldman SA, Rapoport RM, Murad F: Atrial natriuretic factor selectively activates particulate guanylate cyclase and elevates cyclic GMP in rat tissues. J Biol Chem 1984;259:1433214334.

24 Song D-L, Kohse KP, Murad F: Brain natriuretic factor: Augmentation of cellular GMP, activation of particulate guanylate cyclase and receptor binding. FEBS Lett 1989;232:125129.

25 Osajima A, Mutoh Y, Uezono Y, Kawamura M, Izumi F, Takasugi M, Kuroiwa A: Adrenomedullin increases cyclic AMP more potently than CGRP and amylin in rat tubular basolateral membranes. Life Sci 1995;57:457-462.

26 Osajima A, Uezono Y, Tamura M, Kitamura K, Mutoh Y, Ueta Y, Kangawa K, Kawamura M, Eto T, Yamashita H, Izumi F, Takasugi M, Kuroiwa A: Adrenomedullin-sensitive receptors are preferentially expressed in cultured rat mesangial cells. Eur J Pharmacol 1996;315: 319-325.

27 Jougasaki M, Rodeheffer RJ, Redfield MM, Yamamoto K, Wei C-M, Mckinley LJ, Burnett JC Jr: Cardiac secretion of adrenomedullin in human heart failure. J Clin Invest 1996;97: 2370-2376.

28 Nishikimi T, Horio T, Sasaki T, Yoshihara F, Takishita S, Miyata A, Matsuo H, Kangawa K: Cardiac production and secretion of $\mathrm{AM}$ are increased in heart failure. Hypertension 1997; 30:1369-1375.
29 Ishihara T, Yokota S, Hisanaga S, Fujimoto S, Hirayama N, Koto J, Kitamura K, Eto T: Increased plasma levels of mature form of adrenomedullin in patients with chronic renal failure. Clin Nephrol 1999;52:119-123.

30 Washimine H, Yamamoto Y, Kitamura K, Tanaka M, Ichiki Y, Kangawa K, Matsuo H, Eto $\mathrm{T}$ : Plasma concentration of human adrenomedullin in patients on hemodialysis. Clin $\mathrm{Ne}-$ phrol 1995;44:389-393.

31 Letizia C, Mazzaferro S, Chicca S, Cerci S, Subioli S, Cinotti GA, D'Erasmo E: Changes in adrenomedullin plasma concentrations during haemodialysis in patients with chronic renal failure. Nephrol Dial Transplant 1999;14:519_ 520.

32 Mallamaci F, Zoccali C, Parlongo S, Cutrupi S, Triperi G, Postorino M: Plasma adrenomedullin during acute changes in intravascular volume in hemodialysis patients. Kidney Int 1998;54:1697-1703.

33 Toepfer M, Schlosshauer M, Sitter T, Burchardi C, Behr T, Schiffl H: Effects of hemodialysis on circulating adrenomedullin concentrations in patients with end-stage renal disease. Blood Purif 1998;16:269-274.

34 Kato J, Kitamura K, Matsui E, Tanaka M, Ishizaka Y, Kita T, Kangawa K, Eto T: Plasma adrenomedullin and natriuretic peptides in patients with essential or malignant hypertension. Hypertens Res 1999;22:61-65. 